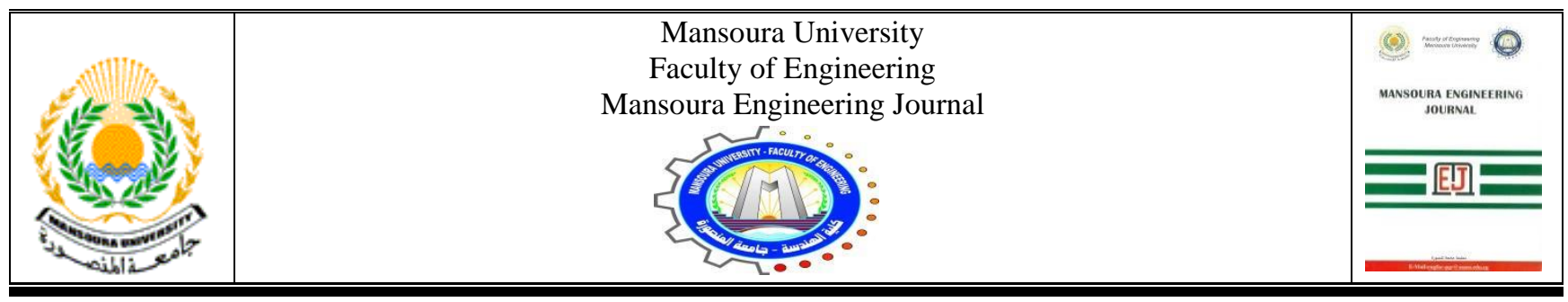

\title{
Proposed Design for Single Axis Photovoltaic Solar Tracker

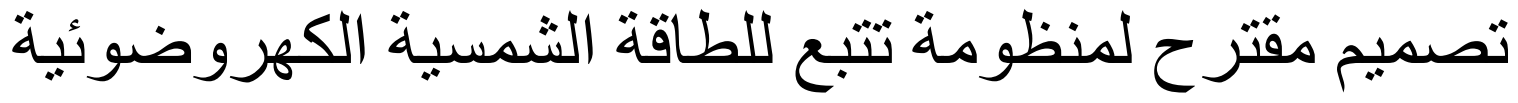

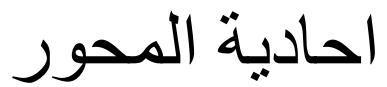

Ammar Bakry, M.Said and Saber.M.Saleh

\author{
KEYWORDS: \\ Tracking system, Solar \\ energy, microcontroller, \\ PVsyst software
}

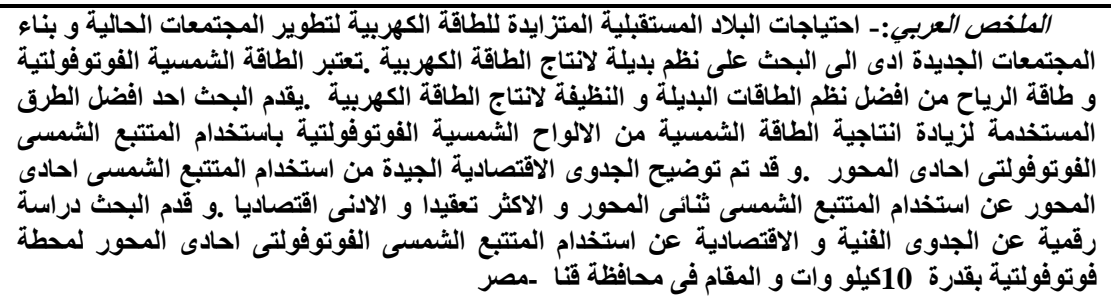

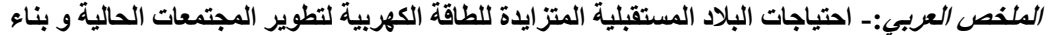

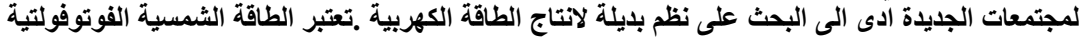

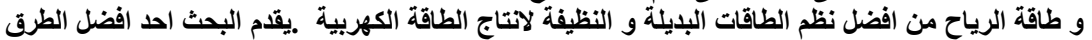

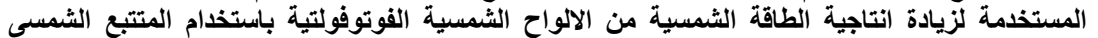

الفوتوفولتى احادى المحور .و قد تم توضيح الجدوى الاقتصادية الجيدة من استخدام المتتبع الشمسى احادى الثيه

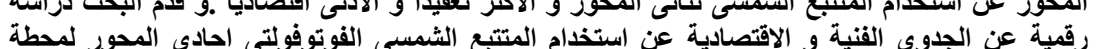

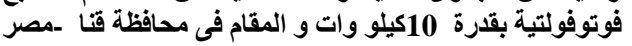

\begin{abstract}
- our energy needs increase day by day, so the search for a renewable source of energy has become a necessity of life. Photovoltaic solar energy (PVSE) is one of the most important sources in our community because it is clean and renewable. This paper discusses improvement the production energy from this source by using practical design of single axis solar tracking system. The designed solar tracking system used microcontroller Arduino Mega, real time clock (RTC), limit switches and servo motor. The mechanism of the designed solar tracker is applied by moving the solar structure to track the sun on better angle to be perpendicular to the sun to get the most energy from it using the RTC and limit switches. Comparison between solar tracking system and fixed system reveal that the system is more economic and larger power production. This tracking system is designed and tested in real environmental in Qena governorate in Egypt. The $10 \mathrm{~kW}$ solar power plants are used as a case study for this system. Comparison between the proposed solar tracking system and the solar fixed system for the
\end{abstract} 2020)

Received: (7 April 2020) - Revised: (10 May 2020) - Accepted: (12 May

Corresponding Author: M.Said. department of electrical engineering faculty of engineering - fayoum university (e-mail: msi01@fayoum.edu.eg)

Saber.M.Saleh, department of electrical engineering - faculty of engineering - fayoum university (e-mail: sms08@fayoum.edu.eg)

Ammar Bakry, researcher at department of electrical engineering faculty of engineering - fayoum university (e-mail: eng3mmarbakry@gmail.com) same demand is performed using PVsyst software as theoretically. Also, economic viability between the two practical systems is produced.

\section{INTRODUCTION}

$\mathrm{N}$ UMEROUS researchers worldwide have increased their attention to the development of renewable energy. Renewable energy sources are friendlier to the environment and more sustainable compared to fossil fuels Renewable energy includes several forms such as solar and wind energy [1-6]. The sun tracking system in different solar energy applications plays an important role where its benefits over the fixed systems not limited to the power and efficiency gains and increase, but also in the large-scale solar energy applications economic analyses [7-13].

The predominant two categories of tracking-single and dual axis tracking-have different features compared to each other. Although the dual-axis tracking is more complicated and has a higher cost, which uses more instruments and equipment [713]. Solar tracking systems can be divided into two main types, namely, active and passive solar tracking systems. Active solar tracking systems use gears and motors to control photovoltaic modules, whereas passive tracking systems use a low boiling-point compressed gas fluid that originates from 
solar heat [1-13]. The sun tracking systems have different based designs and components. The previous studies of the tracker systems can be classified into two main categories; single axis tracker about $42.57 \%$ and dual axis tracker about $41.58 \%$. Active tracker recently used in most applications by about $76.42 \%$ while the chronological tracker used by about $7.55 \%$ as a second impact type. Moreover, the percentages of the other techniques are $16.87 \%$ for the Azimuth and altitude tracker, $16.67 \%$ for the Horizontal tracker, $10 \%$ for the Azimuth tracker and $4.44 \%$ for the polar tracker [7-13].

Single-axis tracking systems are nearly the best solution for small photovoltaic modules. The single-axis system is cheaper than other systems, and it can be moved horizontally or vertically depending on the location of the sun and weather [1$6]$. There are many tracking techniques have not efficient and not reliable sensors not efficient and not reliable to work in outdoor area such as LDR [14-17] and photoelectric sensor [14-16] and GPS module [14], now we will discuss some of these projects and works. This paper used SCM (Single chip microcontroller), Photoelectric-detection circuit, Global Position System (GPS) module, Voltage/current detection circuit; this system has the advantages of high tracking accuracy, fast response and stable performance [14].

Two light dependent resistors (LDR) are used as a sensor for detecting the sun position. And it found The results of the study showed that the single axis tracker system receives average value of the energy received was 1.35 times greater than the fixed panel system, however the dual axis tracker system receives the average value which is only 1.04 times the received energy of a single axis one. Therefore, as compared to double axis system, single axis system is more useful according results obtained from the installed system in the Qeshm Island, Iran [15].

This designed controller can automatically detect sunlight real-time tracking sun, to improve solar panels' photoelectric conversion efficiency. The controller used DSC (digital single controller) as the control core, real time calculates solar position from data collected by sensors, and then sends a signal to control the motor rotation to achieve automatic tracking sun [16].

Arduino Uno microcontrollers that have open-source prototyping platform are used with dual axis based tracker because of its easy for hardware interrupt and software programming. The solar tracker can automatically be controlled with the Light Dependent Resistor (LDR) sensors or manually using a potentiometer from the experimental results, it is noticed that the generation of the PV system using the solar tracker is increased up to $35.16 \%$ when compared to the fixed-axis PV panel [17-22].

There are some projects used microcontroller and stepper motor. Microcontroller was used to reduce the complexity of the circuit. This system works effectively irrespective of the weather condition or the geographical location [23].

The efficiencies of the open- and closed-loop tracking types are discussed, but we can improve the closed loop tracking by using reliable and simple sensors like limit switches [24]. New technique where those two drawbacks have been addressed.
The design uses a microcontroller-based control mechanism to maximize solar energy extraction. This is done by the design of a tracking system known as the PILOT and cells rotating system known as PANEL. First the system is oriented towards the east waiting for sun to rise. When this happens, the PILOT keeps tracking the sun. This is done with the aid of a light to frequency converter (LTF) mounted on a miniature electric motor. This converter always lines the PILOT with the sun. Two identical light dependent resistors (LDR) are mounted, by comparative study, which shows an increase of energy extraction by about $40 \%$ over fixed panels [25].

A hybrid algorithm located the sun position automatically using microcontroller by combined mathematical models and sensors so, for all weather conditions it will gain the optimal solar energy. With a large-scale implementation, the proposed hybrid solar tracker can harness optimal solar energy for all weather conditions [26].

Evaluation of the proposed tracking system is performed by comparing several elements with other tracking system. The elements are tracking technique, simplicity of mechanical structure, performance of electrical structure, accuracy, reliability, and percentage of increasing energy. Table 1 explains this comparison. The energy required for the tracking system is small and may be neglected or may be feed from a fixed solar module.

This paper proposed single axis tracking; the collector rotated over a north-south axis. This paper aims to maximize energy produced from PV solar system by using tracking solar system. Tracking system is designed and tested in real environmental in Qena governorate in Egypt. Comparison between the proposed solar tracking system and the fixed system power production and economic aspect is produced. The organization of this paper is as follows; section 1 is introduction, section 2 describe the implementation of hardware tracking system, section 3 show the algorithm applied to microcontroller for tracking system, section 4 produced the algorithm applied to microcontroller for tracking system. Section 5 Energy production comparison between fixed and tracking solar system, Section 6 Economic comparison between fixed and tracking solar system and finally conclusion section.

\section{HARDWARE IMPLEMENTATION FOR TRACKING SYSTEM.}

The components of solar tracking system are explained in Fig.1. The system contains PV module, battery, servo motor, charge controller, limit switch, micro controller, real time clock, light emitting diode, push button and liquid crystal display. 
TABLE 1

COMPARISON BETWEEN THE PROPOSED SYSTEM AND OTHER SYSTEMS

\begin{tabular}{|c|c|c|c|c|c|c|}
\hline Paper & Tracking technique & $\begin{array}{l}\text { Mechanical } \\
\text { structure }\end{array}$ & $\begin{array}{l}\text { Electrical } \\
\text { structure }\end{array}$ & Accuracy & Reliability & $\begin{array}{l}\text { \% increasing } \\
\text { in energy }\end{array}$ \\
\hline \multirow{3}{*}{$\begin{array}{c}\text { The } \\
\text { proposed } \\
\text { method }\end{array}$} & Servo motor & \multirow{3}{*}{ Simple } & \multirow[t]{3}{*}{ Very good } & \multirow[t]{3}{*}{ Accurate } & \multirow[t]{3}{*}{ Very reliable } & \multirow[t]{3}{*}{$30.4 \%$} \\
\hline & Limit switches & & & & & \\
\hline & RTC (real time clock) & & & & & \\
\hline \multirow{3}{*}{$\operatorname{Ref}[14]$} & GPS & \multirow[t]{3}{*}{ Not specify } & \multirow{3}{*}{$\begin{array}{c}\text { Not } \\
\text { specify }\end{array}$} & \multirow[t]{3}{*}{ Accurate } & \multirow[t]{3}{*}{ Not reliable } & \multirow[t]{3}{*}{ Not specify } \\
\hline & Photovoltaic sensor & & & & & \\
\hline & $\begin{array}{l}\text { Voltage and current } \\
\text { detector }\end{array}$ & & & & & \\
\hline Ref [15] & 2 LDR & Complex & Good & Accurate & Not reliable & $35 \%$ \\
\hline \multirow{2}{*}{$\operatorname{Ref}[16]$} & DCS \& RTC & \multirow[t]{2}{*}{ Complex } & \multirow[t]{2}{*}{ Good } & \multirow[t]{2}{*}{ Accurate } & \multirow[t]{2}{*}{ reliable } & \multirow[t]{2}{*}{$14 \%$} \\
\hline & Photovoltaic sensor & & & & & \\
\hline \multirow{2}{*}{$\operatorname{Ref}[17]$} & LDR & \multirow[t]{2}{*}{ Simple } & \multirow[t]{2}{*}{ Good } & \multirow[t]{2}{*}{ Accurate } & \multirow[t]{2}{*}{ Not reliable } & \multirow[t]{2}{*}{$36.16 \%$} \\
\hline & Potentiometer & & & & & \\
\hline \multirow{2}{*}{$\operatorname{Ref}[23]$} & Microcontroller & \multirow[t]{2}{*}{ Simple } & \multirow[t]{2}{*}{ Good } & \multirow[t]{2}{*}{ Accurate } & \multirow[t]{2}{*}{ reliable } & \multirow[t]{2}{*}{ Not specify } \\
\hline & Stepper motor & & & & & \\
\hline
\end{tabular}

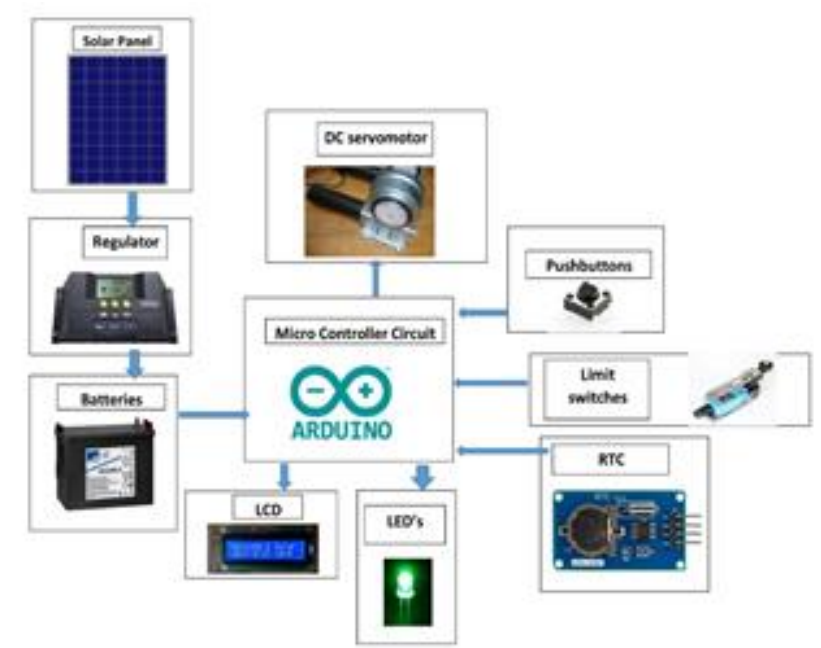

Fig.1 Configuration of system components

\section{A. PV Panel}

PV panel used to feed electric power for the batteries by using charger controller this table specifies specification of this solar panel

TABLE 2

THE SPECIFICATION OF THIS SOLAR PANEL

\begin{tabular}{c||c} 
Power & $265 \mathrm{~W}$ \\
\hline Rated voltage & $30.7 \mathrm{~V}$ \\
\hline Rated current & $8.47 \mathrm{~A}$
\end{tabular}

\section{B. Charger controller}

Charger controller used to regulate the voltage and the current to charging the batteries as shown in Fig.2. The electrical specification for the charger controller shows in Table 3.

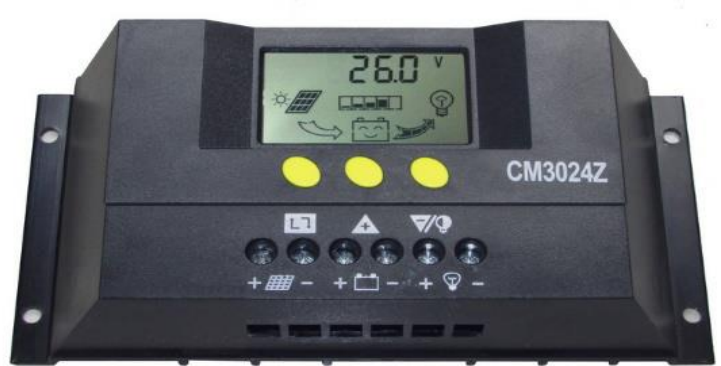

Fig.2. Charge controller used in the system

TABLE 3

THE ELECTRICAL SPECIFICATION FOR THE CHARGER CONTROLLER

\begin{tabular}{l||c} 
Rated charging current & $30 \mathrm{~A}$ \\
\hline Rated charging voltage & $24 \mathrm{~V}$
\end{tabular}

\section{Battery}

Batteries are used to supply electric power for tracking control systems the system has two batteries' connected in series to get $24 \mathrm{v}$ to each batteries capacity $12 \mathrm{~V} 200 \mathrm{Ah}$, as shown in Fig.3.

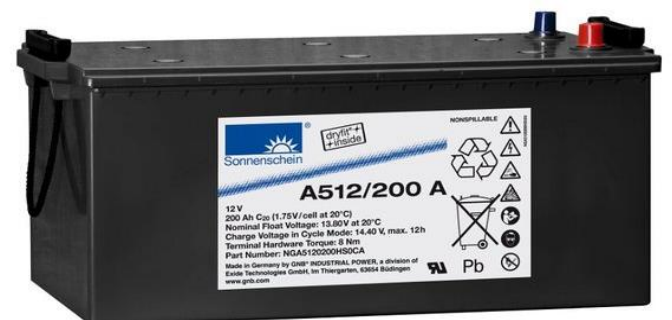

Fig.3. Battery used in the system

\section{Servomotor}

Servomotor is a Dc motor with gearbox to reduce the speed of motor as shown in Fig.4; it uses to rotate the panel structure from east to west the general specification for this motor is explained in Table 4. This tracking system has control in six motor start and stop and reverse direction. 
TABLE 4

GENERAL SPECIFICATION FOR SERVO MOTOR

\begin{tabular}{c||c} 
Voltage & $24 \mathrm{~V}$ \\
\hline Rated Current & $4 \mathrm{~A}$ \\
\hline RPM & $1 \mathrm{RPM}$
\end{tabular}

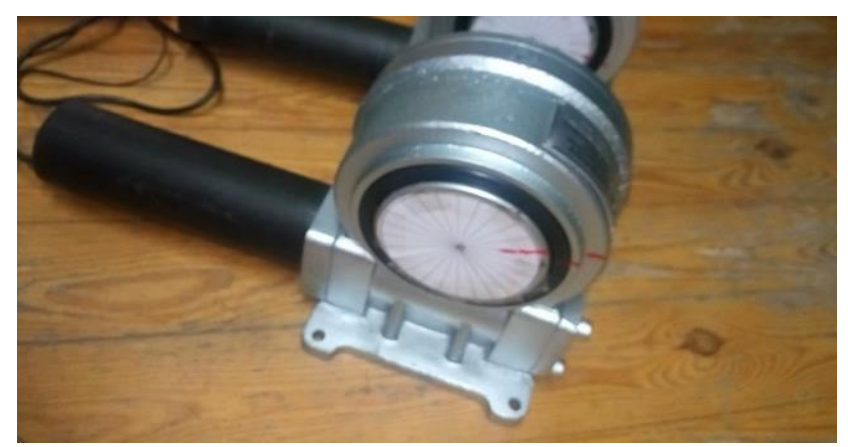

Fig.4. Servo motor used in the system

\section{E. Limit switch}

The limit switch it used to sense the motor position and to limit it is path from east to west or from west to east; as shown in Fig.5. It best chose for this application because it has mechanical switch suitable for outdoor and dusty area.
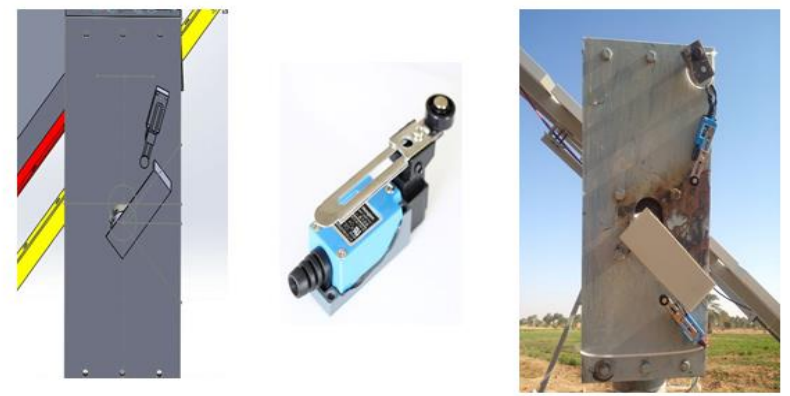

Fig.5. Limit switch used in the system

\section{F. Microcontroller}

The multi things controlled from one place by using Arduino Mega the maximum optimization for use because all pins in Arduino mega used to control in multi things from one place to minimize the cost. The Arduino Mega 2560 is a microcontroller board based on the ATmega2560. It has 54 digital input / output pins (of which 14 as PWM output available), 16 analog inputs, 4 UARTs (hardware serial ports), a $16 \mathrm{MHz}$ crystal oscillator, a USB connection, a power jack, an ICSP header, and a reset button; as shown in Fig.6.

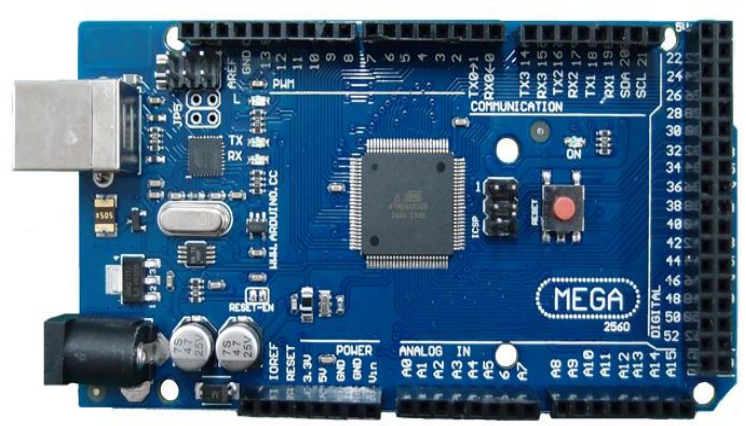

Fig.6. Microcontroller circuit used in the system

\section{G. Real time clock}

RTC DS1307 is the module used to send real and accurate time for Arduino mega without any delay time to control in motor position to track the sun in special time clock; as in Fig.7.

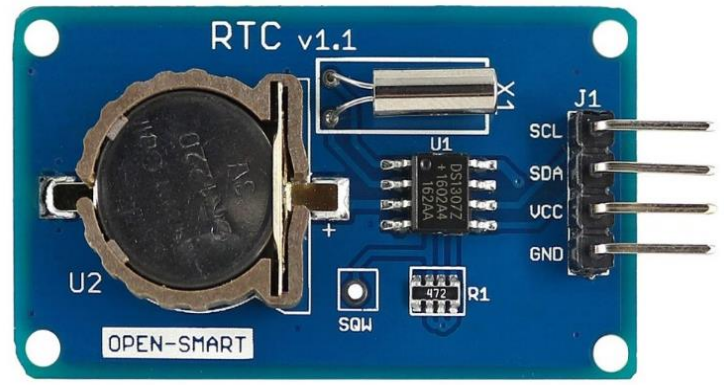

Fig.7. Real time clock circuit used in the system

\section{H. Liquid crystal display}

LCD used to display time and position of motor at this time; as shown in Fig.8.

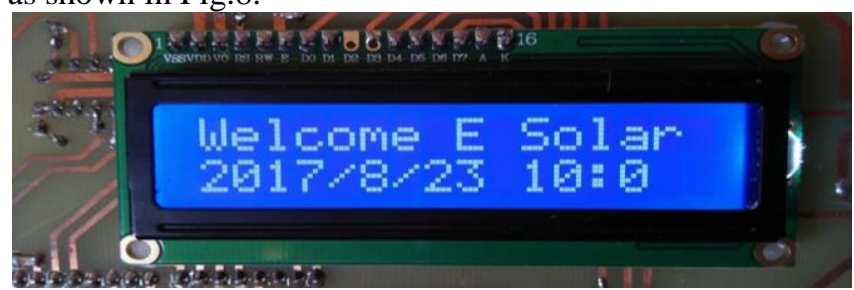

Fig.8. Liquid crystal display used in the system

\section{Push buttons}

Push buttons used for rotate motors from east to west or from west to east manually to set motor in initial position in our system we have three push buttons the first to rotate motor forward and the second to rotate motor reverse and the third to reset program; as in Fig.9. 

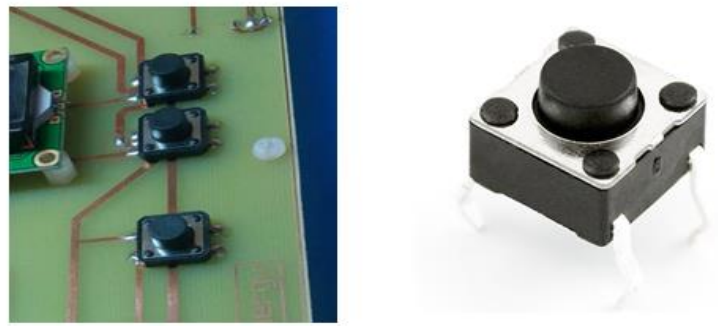

Fig.9. Push button switch used in the system

\section{J. Light emitting diodes}

LED's used to indicate the motor steps, the system track the sun with seven steps every step has LED to light up when system reach in this step; as shown in Fig.10.
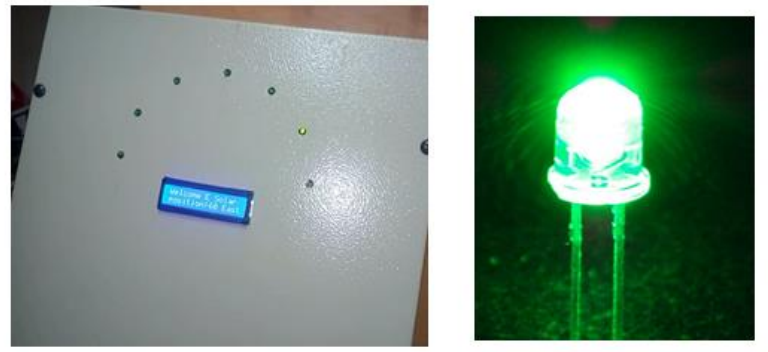

Fig.10. Light emitting diodes used in the system

\section{Practical Mechanical and Electrical HARDWARE DESIGN}

\section{A. Mechanical hardware design}

From sunrise to sunset, the single axis tracking system followed the sun in the sky from the east to the west through the day as shown if Fig. 11. The mechanism rotates only around a single axis in one plane so, it called single axis. The cells can be oriented by the single axis from stand up at a tilt (polar axis) to lie flat (horizontal axis). This single axis technique is less expensive and simple compared by the other methods. The single axis technique is effective method for all locations, even the closer to the equator where the sun's arc is less variable through the day.
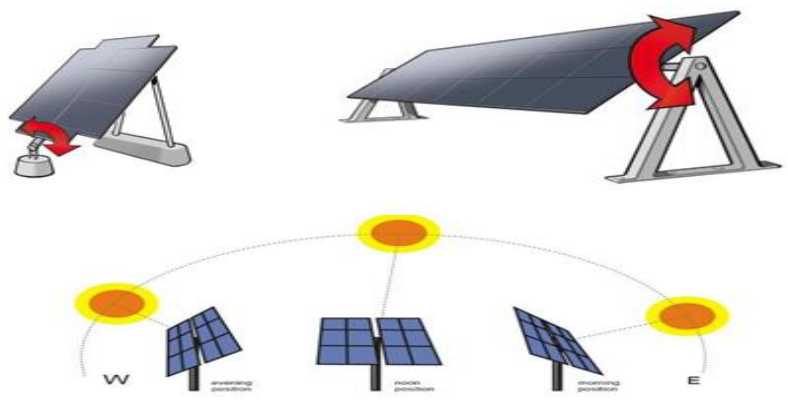

Fig.11. Single axis sun tracker

The Single-pivot horizontal sun trackers are structurally more rigid and stable, and hence it is less likely to be damaged during storms. Moreover, the Single-axis horizontal trackers are also structurally more rigid and stable, and hence less likely to be damaged during storms. In addition to that the properties in normal single-axis are achieved in single-axis horizontal trackers. Fig. 12 and 13 are explained the 3-D and real design for solar tracking system.

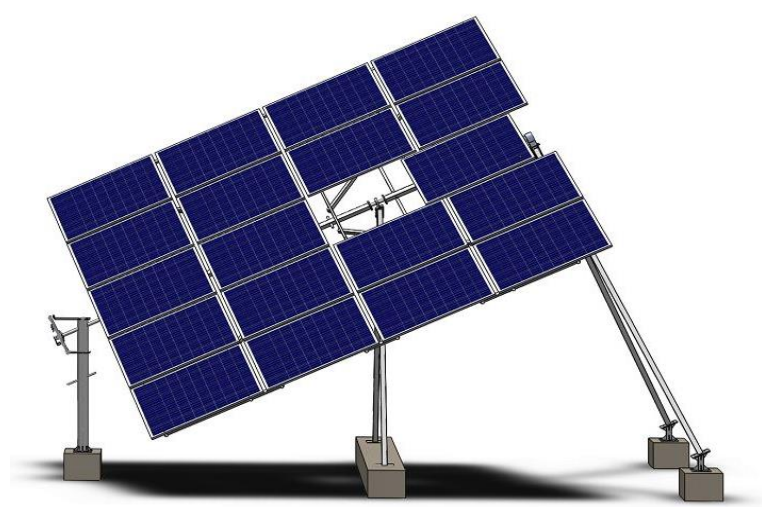

Fig.12. The 3-D solar tracking system

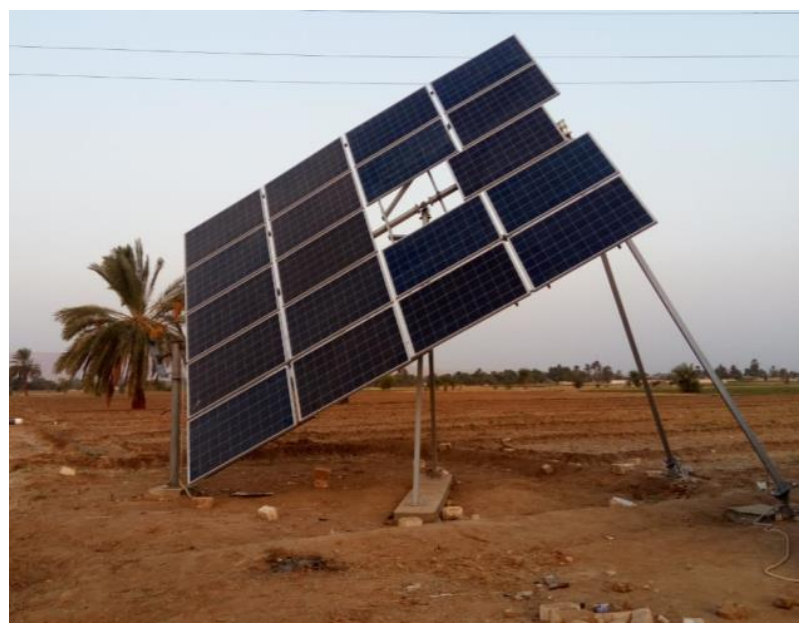

Fig.13. The real solar tracking system

\section{B. Electrical hardware design}

1- The initial design

The electrical design starts as prototype to making simulation for the real system, and to find the problems, which the system subjected to it. At the initial design, motor movement and its steps was dependent on the delay time by using timer included in microcontroller, but after a while we noticed that more shift in time occurs and the steps not come on the time, so we turned to use an RTC, Which give real and accurate time for microcontroller. After that problem was solved, another problem appears, there are shifts in motor movement to solve this problem limit switches were used to limit the shift in motor movements. The initial electrical hardware design is appeared in Fig. 14. 


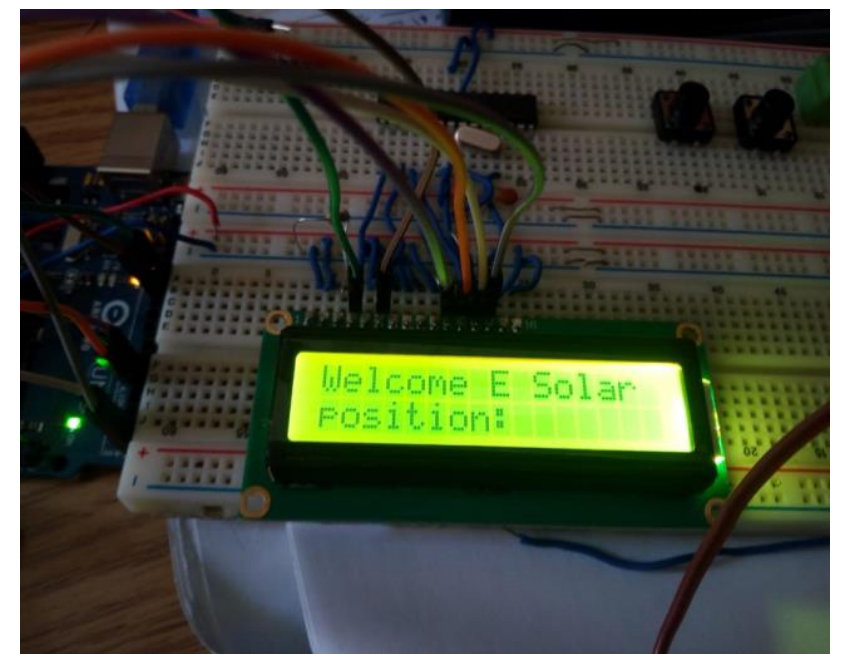

Fig.14. The initial electrical hardware design for the tracking system

2- The final design

The final design has optimization in the control circuit and solve all problems in initial design, the control circuit can control in six motors by using one RTC (real time clock) and twelve limit switches each motor has two limit switches one of them to limit rotation in east direction and the other for the west.

The control circuit has two options for control manual and automatic by using push button's the user can control in the movement of motors manually. This control circuit has seven LED to indicating light at every step and it has LCD to display the real time and the position of the system, these pictures describe the electric circuit design and its components. The final electrical hardware design is appeared in Fig. 15. Arduino mega pin connection is described in Fig. 16.

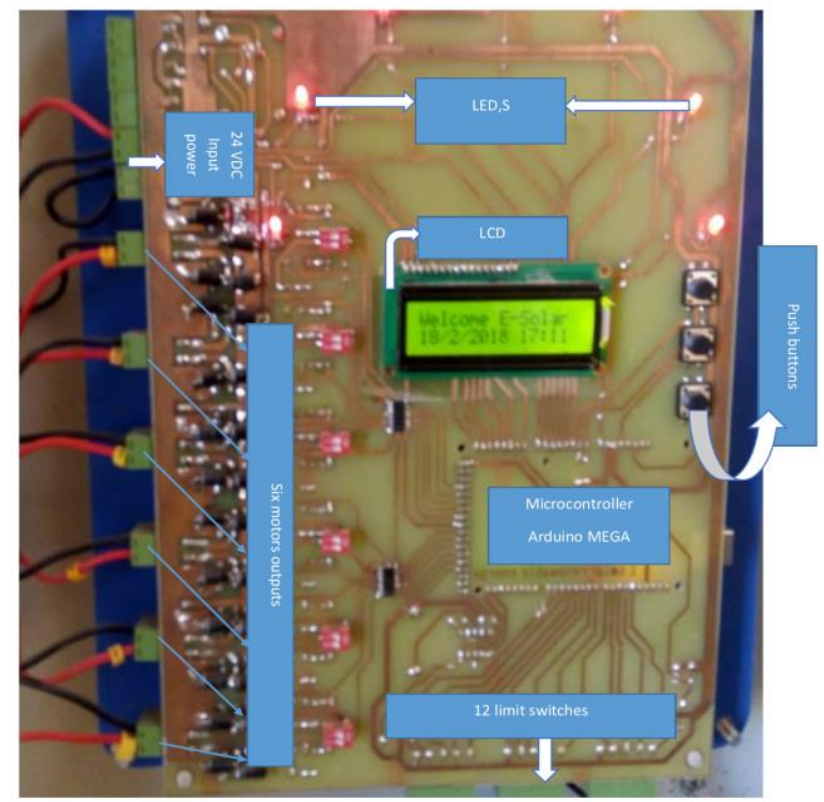

Fig.15. The final electrical hardware design for the tracking system

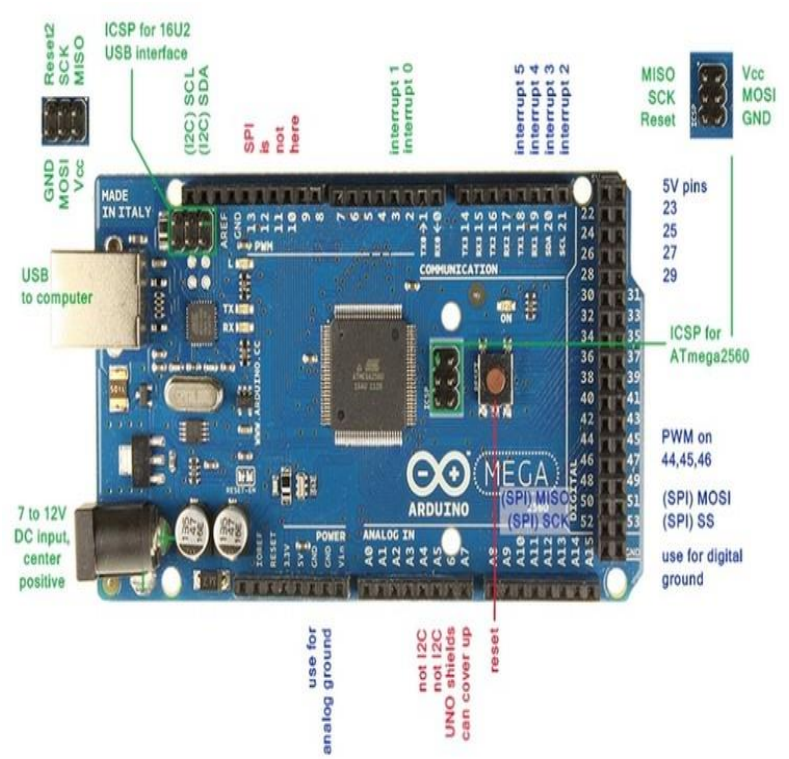

Fig.16. The Arduino mega pin connection used in tracking system

The printed circuit board consisting of:

1. Input and output power

The input voltage for this board $24 \mathrm{~V}$, it has (7805) regulator to regulate $5 \mathrm{~V}$ to feed the Arduino control circuit and it has (7812) to regulate the $12 \mathrm{~V}$ output to supply power for external fan.

2. Output pins

* The six motors connected at 12 output pins through 12 relays each motor has two relays, one of them for forward (R1) and other for reverse (R2).

* The LCD connected at 6 output pins from A10 to A15.

* The LEDs connected at seven output pins from A2 to A8.

3. Input Pins

* The limit switches connected at 12 input pins each motor has two limit switches to stop motor at end of the forward and reverse steps.

* The Push buttons connected at 2 input pins (A0, A1)

* The RTC connected at 2 input pins (P20, P21)

Table 5 descried the details connections of the pins on the printed circuit board to the microcontroller. 
TABLE 5

THE PINS DESCRIPTION ON THE CIRCUIT BOARD

\begin{tabular}{|c|c|c|c|c|c|}
\hline Function & PIN & Comment & Function & PIN & Comment \\
\hline$S W(U p)$ & A0 & $\begin{array}{l}\text { Active } \\
\text { High }\end{array}$ & $\begin{array}{c}\text { Limit } \\
\text { Switch } 6\end{array}$ & P7 & $\begin{array}{l}\text { Active } \\
\text { Low }\end{array}$ \\
\hline $\begin{array}{c}S W(\text { Down } \\
\text { ) }\end{array}$ & A1 & $\begin{array}{l}\text { Active } \\
\text { High }\end{array}$ & $\begin{array}{c}\text { Limit } \\
\text { Switch } 7\end{array}$ & P6 & $\begin{array}{l}\text { Active } \\
\text { Low }\end{array}$ \\
\hline LED1 & A8 & $\begin{array}{l}\text { Active } \\
\text { High }\end{array}$ & $\begin{array}{c}\text { Limit } \\
\text { Switch } 8\end{array}$ & P5 & $\begin{array}{l}\text { Active } \\
\text { Low }\end{array}$ \\
\hline$L E D 2$ & A7 & $\begin{array}{l}\text { Active } \\
\text { High }\end{array}$ & $\begin{array}{c}\text { Limit } \\
\text { Switch } 9\end{array}$ & $\mathrm{P} 4$ & $\begin{array}{l}\text { Active } \\
\text { Low }\end{array}$ \\
\hline$L E D 3$ & A6 & $\begin{array}{l}\text { Active } \\
\text { High }\end{array}$ & $\begin{array}{c}\text { Limit } \\
\text { Switch } \\
10\end{array}$ & P3 & $\begin{array}{l}\text { Active } \\
\text { Low }\end{array}$ \\
\hline LED4 & A5 & $\begin{array}{l}\text { Active } \\
\text { High }\end{array}$ & $\begin{array}{c}\text { Limit } \\
\text { Switch } \\
11\end{array}$ & $\mathrm{P} 2$ & $\begin{array}{l}\text { Active } \\
\text { Low }\end{array}$ \\
\hline LED5 & A4 & $\begin{array}{l}\text { Active } \\
\text { High }\end{array}$ & $\begin{array}{c}\text { Limit } \\
\text { Switch } \\
12 \\
\end{array}$ & P1 & $\begin{array}{l}\text { Active } \\
\text { Low }\end{array}$ \\
\hline LED6 & A 3 & $\begin{array}{l}\text { Active } \\
\text { High }\end{array}$ & & & \\
\hline LED7 & $\mathrm{A} 2$ & $\begin{array}{l}\text { Active } \\
\text { High }\end{array}$ & $\begin{array}{l}\text { Motor } 1 \\
\text { Relay } 1 \\
\end{array}$ & P49 & $\begin{array}{l}\text { Active } \\
\text { High }\end{array}$ \\
\hline$L C D(D 4)$ & A13 & - & $\begin{array}{l}\text { Motor } 1 \\
\text { Relay } 2 \\
\end{array}$ & $\mathrm{P} 47$ & $\begin{array}{l}\text { Active } \\
\text { High }\end{array}$ \\
\hline$L C D(D 5)$ & A12 & - & $\begin{array}{l}\text { Motor } 2 \\
\text { Relay } 1\end{array}$ & $\mathrm{P} 45$ & $\begin{array}{l}\text { Active } \\
\text { High }\end{array}$ \\
\hline$L C D(D 6)$ & A11 & - & $\begin{array}{l}\text { Motor } 2 \\
\text { Relay } 2 \\
\end{array}$ & $\mathrm{P} 43$ & $\begin{array}{l}\text { Active } \\
\text { High }\end{array}$ \\
\hline$L C D(D 7)$ & A10 & - & $\begin{array}{l}\text { Motor } 3 \\
\text { Relay } 1 \\
\end{array}$ & $\mathrm{P} 41$ & $\begin{array}{l}\text { Active } \\
\text { High }\end{array}$ \\
\hline$L C D(R S)$ & A15 & - & $\begin{array}{l}\text { Motor } 3 \\
\text { Relay } 2 \\
\end{array}$ & P39 & $\begin{array}{l}\text { Active } \\
\text { High }\end{array}$ \\
\hline$L C D(E N)$ & A14 & - & $\begin{array}{l}\text { Motor } 4 \\
\text { Relay } 1 \\
\end{array}$ & P37 & $\begin{array}{c}\text { Active } \\
\text { High }\end{array}$ \\
\hline$R T C(S D A)$ & $\mathrm{P} 20$ & - & $\begin{array}{l}\text { Motor } 4 \\
\text { Relay } 2 \\
\end{array}$ & P35 & $\begin{array}{l}\text { Active } \\
\text { High }\end{array}$ \\
\hline$R T C(S C L)$ & P21 & - & $\begin{array}{l}\text { Motor } 5 \\
\text { Relay } 1 \\
\end{array}$ & P33 & $\begin{array}{l}\text { Active } \\
\text { High }\end{array}$ \\
\hline $\begin{array}{c}\text { Limit } \\
\text { Switch } 1\end{array}$ & P12 & $\begin{array}{l}\text { Active } \\
\text { Low }\end{array}$ & $\begin{array}{l}\text { Motor } 5 \\
\text { Relay } 2\end{array}$ & P31 & $\begin{array}{l}\text { Active } \\
\text { High }\end{array}$ \\
\hline $\begin{array}{c}\text { Limit } \\
\text { Switch } 2\end{array}$ & P11 & $\begin{array}{l}\text { Active } \\
\text { Low }\end{array}$ & $\begin{array}{l}\text { Motor } 6 \\
\text { Relay } 1 \\
\end{array}$ & P29 & $\begin{array}{l}\text { Active } \\
\text { High }\end{array}$ \\
\hline $\begin{array}{c}\text { Limit } \\
\text { Switch } 3\end{array}$ & P10 & $\begin{array}{l}\text { Active } \\
\text { Low }\end{array}$ & $\begin{array}{l}\text { Motor } 6 \\
\text { Relay } 2 \\
\end{array}$ & $\mathrm{P} 27$ & $\begin{array}{l}\text { Active } \\
\text { High }\end{array}$ \\
\hline $\begin{array}{c}\text { Limit } \\
\text { Switch } 4\end{array}$ & $\mathrm{P} 9$ & $\begin{array}{l}\text { Active } \\
\text { Low }\end{array}$ & & & \\
\hline $\begin{array}{c}\text { Limit } \\
\text { Switch } 5\end{array}$ & P8 & $\begin{array}{l}\text { Active } \\
\text { Low }\end{array}$ & & & \\
\hline
\end{tabular}

\section{THE ALGORITHM APPLIED TO MICROCONTROLLER FOR TRACKING SYSTEM}

Flow chart in Fig. 17 describes the algorithm used in tracking system. The solar tracking control system has two options for control manual and automatic.

\section{A. Manual control}

Manual control option is preferred in some cases; case 1 is if the users need to select the suitable angle position and preferably in maintenance cases. Manual control option will be active if push buttons which connected on A0 or A1 ports are activated by user, when port A0 is active the tracking system will rotate from east to west and the system will rotate from west to east if port A1 is activated.

\section{B. Automatic control}

If the $\mathrm{A} 0$ and $\mathrm{A} 1$ not activated the system will be tracked the sun from east to west automatically the motor will be rotated forward (from east to west) by six steps and will be rotated reverse (from west to east) in one step.

\section{Forward step}

At every step forward the microcontroller will check the real time and case of limit switch LS1 (Limit switch 1). If LS1 is not activated the system will be rotated at this duration of time and will be stopped the rotation if the duration of time is end or the limit switch LS1 is activated, the six forward steps will be taken the time according to Table 6 .

TABLE 6

THE SIX FORWARD STEPS USED IN MICROCONTROLLER

\begin{tabular}{|c|c|c|c|c|}
\hline \multicolumn{2}{|r|}{ Step } & Angel & From & To \\
\hline 1 & Forward & 45 east to 25 east & $8: 00 \mathrm{AM}$ & 8:01 AM \\
\hline 2 & Forward & 25 east to 15 east & 9:00 AM & 9:01 AM \\
\hline 3 & Forward & 15 east to 0 & 10:00 AM & 10:01 AM \\
\hline 4 & Forward & 0 to 15 west & 13:00 PM & 13:01 PM \\
\hline 5 & Forward & 15 west to 25 west & 14:00 PM & 14:01 PM \\
\hline 6 & Forward & 25 west to 45 west & 15:00 PM & 15:01 PM \\
\hline 7 & Reverse & 45 west to 45 east & 18:00 PM & 18:06 PM \\
\hline
\end{tabular}

\section{Reverse step}

At the end of the day light, the system will be rotated reverse (from west to east) at the specified time (18:00 PM) and the limit switch LS2 is not activated if the duration of time is end at (18:06) or LS2 is activated the system will be stopped at sun set position. This process will repeat every day.

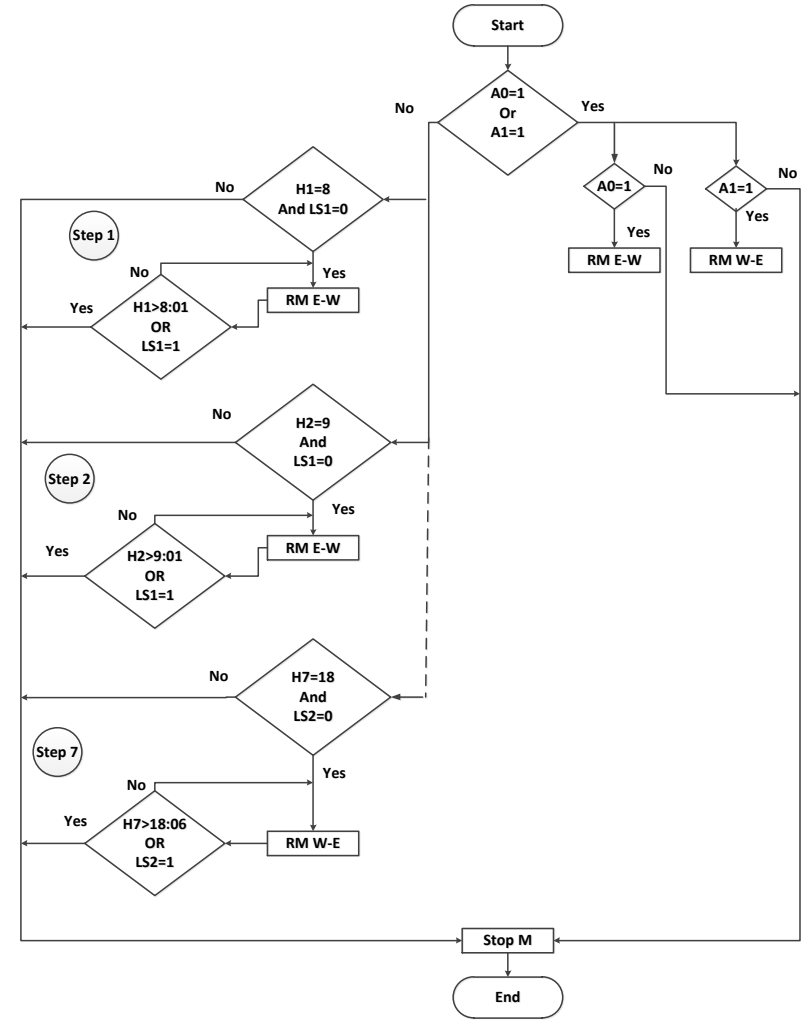

Fig.17. Flow chart for algorithm used in tracking system 


\section{ENERGY PRODUCTION COMPARISON BETWEEN FIXED AND TRACKING SOLAR SYSTEM}

The solar power plant with rate $10 \mathrm{~kW}$ is used for comparison between fixed solar system and tracking solar system. The simulation of the two systems is applied by using PVsyst software. Fig.18 explains the screen shoot of orientation parameters for fixed solar system. Fig.19 explains the screen shoot of orientation parameters for tracking solar system.

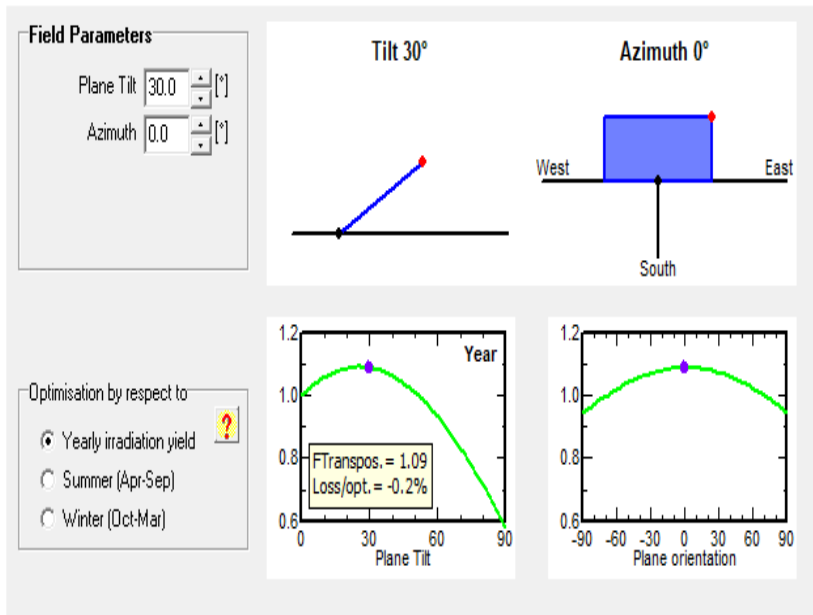

Fig.18. The screen shoots of orientation parameters for fixed solar system

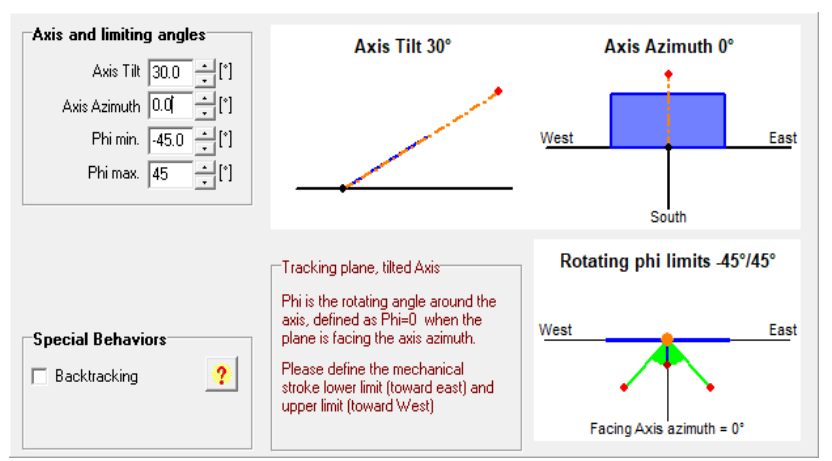

Fig.19. the screen shoots of orientation parameters for tracking solar system

The variation of the yearly Reference Incident Energy in coll. plane (Yr) in $\mathrm{kWh} / \mathrm{m}^{2}$ at day, Normalized Array Production (Lc) in $\mathrm{kWh} / \mathrm{m}^{2}$ at day, Normalized Array Production at peak power (Ya) in $\mathrm{kWh} / \mathrm{m}^{2}$ at day, Normalized System Losses (Ls) in $\mathrm{kWh} / \mathrm{m}^{2}$ at day, Normalized System Production at peak power (Yf) in $\mathrm{kWh} / \mathrm{m}^{2}$ at day, Array Loss / Incident Energy Ratio (Lcr) in $\mathrm{kWh} / \mathrm{m}^{2}$ at day, System Loss / Incident Energy Ratio (Lsr) in $\mathrm{kWh} / \mathrm{m}^{2}$ at day, and Performance Ratio (PR) is described in Table 7 for fixed solar system and in Table 8 for tracking solar system.

The monthly hourly sums production energy for the two systems is described in Table 9 and 10. From these Tables, we observed that; the tracker system increases in productivity as follows; At 5 AM fixed system total output energy $6 \mathrm{kWh}$, while the tracker system total output energy at the same hour
$44 \mathrm{kWh}$. At 5 PM fixed system total output energy $80 \mathrm{kWh}$, while the tracker system total output energy at the same hour $559 \mathrm{kWh}$.

The tracker system increases the number of hours the system works because the total output energy at 6 PM for fixed system is $0 \mathrm{kWh}$, while the tracker system totals output energy at the same hour $7 \mathrm{kWh}$.

The monthly energy production for the fixed and tracking solar system is shown in Fig. 20. From this data the total annual Production energy for fixed system is equal to 19.450 MWH. The total annual Production energy for tracking system is equal to $25.378 \mathrm{MWH}$. From this result, it is noticed that the generation of the PV system using the solar tracker is increased up to $30.4 \%$ when compared to the fixed-axis PV panel. That means that the solar tracker with the used algorithm is able to receive more light as compared to the fixed-axis solar panel.

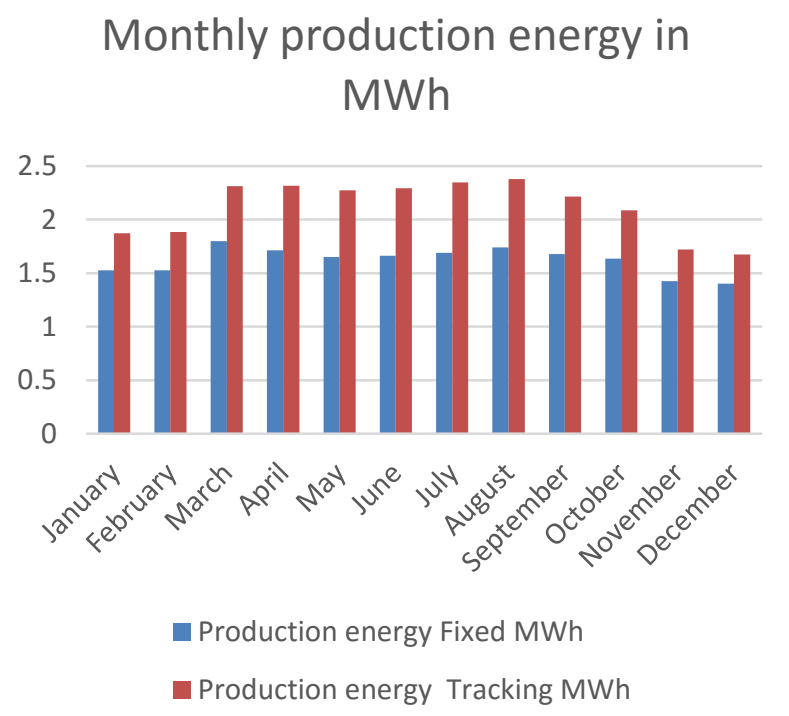

Fig.20. The monthly energy production for the fixed and tracking solar system.

\section{ECONOMIC COMPARISON BETWEEN FIXED AND TRACKING SOLAR SYSTEM}

The cost of the solar fixed system and solar tracking system is analyzed in this section. The elements used in the solar fixed system are photovoltaic modules, inverter, mounting structure, cables, cables trays and protection box. Elements used in the solar tracking system are photovoltaic modules, inverter, mounting structure, cables, cables trays, protection box, servo motor, batteries, charger, control box and limit switches. Table 11 and Table 12 explain the cost of the elements of the two systems in addition to installation cost and transportation cost. The power station mentioned in this study contains 38 solar energy panels in the case of the fixed system while the tracking system contains 39 solar panels; 38 of them is designed as solar tracking system that is compared with fixed system and one of these panels is set separately fixed to feed the control circuit of the solar tracking. The cost of the energy required for the solar tracking control system 
and its component are described in table 11 as explain in items

(7:12).

TABLE 7

\begin{tabular}{|c|c|c|c|c|c|c|c|c|}
\hline & \multicolumn{8}{|c|}{$S O$} \\
\hline & $\mathrm{kWh} / \mathrm{m}^{2}$ & $k W h / m^{2}$ & $\mathrm{kWh} / \mathrm{m}^{2}$ & $\mathrm{kWh} / \mathrm{m}^{2}$ & $\mathrm{kWh} / \mathrm{m}^{2}$ & $\mathrm{kWh} / \mathrm{m}^{2}$ & $\mathrm{kWh} / \mathrm{m}^{2}$ & ratio \\
\hline & & & $\begin{array}{l}\text { at peak } \\
\text { power }\end{array}$ & & $\begin{array}{l}\text { at peak } \\
\text { power }\end{array}$ & & & \\
\hline Jan & 5.60 & 0.57 & 5.03 & 0.14 & 4.89 & 0.101 & 0.024 & 0.874 \\
\hline $\mathrm{Feb}$ & 6.29 & 0.72 & 5.57 & 0.15 & 5.42 & 0.114 & 0.025 & 0.861 \\
\hline Mar & 6.86 & 0.92 & 5.94 & 0.17 & 5.77 & 0.135 & 0.025 & 0.840 \\
\hline$A p r$ & 6.92 & 1.09 & 5.83 & 0.16 & 5.67 & 0.157 & 0.024 & 0.819 \\
\hline May & 6.52 & 1.08 & 5.44 & 0.15 & 5.29 & 0.165 & 0.024 & 0.811 \\
\hline Jun & 6.89 & 1.22 & 5.67 & 0.17 & 5.50 & 0.177 & 0.024 & 0.799 \\
\hline Jul & 6.80 & 1.23 & 5.57 & 0.16 & 5.41 & 0.180 & 0.023 & 0.796 \\
\hline Aug & 7.01 & 1.28 & 5.73 & 0.16 & 5.57 & 0.182 & 0.023 & 0.795 \\
\hline Sep & 6.92 & 1.2 & 5.72 & 0.16 & 5.56 & 0.174 & 0.023 & 0.803 \\
\hline$O c t$ & 6.36 & 0.98 & 5.38 & 0.14 & 5.24 & 0.153 & 0.023 & 0.824 \\
\hline Nov & 5.56 & 0.71 & 4.85 & 0.13 & 4.72 & 0.126 & 0.025 & 0.849 \\
\hline$D e c$ & 5.15 & 0.54 & 4.61 & 0.12 & 4.49 & 0.104 & 0.025 & 0.871 \\
\hline Year & 6.41 & 0.9617 & 5.44 & 0.1508 & 5.29 & 0.150 & 0.024 & 0.826 \\
\hline
\end{tabular}

TABLE 8

\begin{tabular}{|c|c|c|c|c|c|c|c|c|}
\hline & \\
\hline & $\frac{I r}{k W h / m^{2}}$ & $\frac{L c}{L W h / m^{2}}$ & $\frac{\mathrm{ra}}{2}$ & $\frac{L s}{2}$ & $\frac{Y J}{{ }^{2}}$ & $\frac{L c r}{2}$ & Lsr & $P R$ \\
\hline & $\mathrm{kWh} / \mathrm{m}^{2}$ & $\mathrm{kWh} / \mathrm{m}^{2}$ & $\begin{array}{l}\mathrm{kWh} / \mathrm{m}^{2} \\
\text { at peak } \\
\text { power }\end{array}$ & $\mathrm{kWh} / \mathrm{m}^{2}$ & $\begin{array}{l}\mathrm{kWh} / \mathrm{m}^{2} \\
\text { at peak } \\
\text { power }\end{array}$ & $\mathrm{kWh} / \mathrm{m}^{2}$ & $\mathrm{kWh} / \mathrm{m}^{2}$ & ratio \\
\hline Jan & 6.89 & 0.73 & 6.16 & 0.16 & 6.00 & 0.105 & 0.024 & 0.871 \\
\hline $\mathrm{Feb}$ & 7.82 & 0.94 & 6.88 & 0.2 & 6.68 & 0.120 & 0.025 & 0.855 \\
\hline Mar & 8.86 & 1.24 & 7.62 & 0.21 & 7.41 & 0.140 & 0.024 & 0.836 \\
\hline Apr & 9.36 & 1.47 & 7.89 & 0.22 & 7.67 & 0.157 & 0.023 & 0.820 \\
\hline May & 8.94 & 1.46 & 7.48 & 0.2 & 7.28 & 0.163 & 0.023 & 0.814 \\
\hline Jun & 9.48 & 1.68 & 7.80 & 0.21 & 7.59 & 0.177 & 0.023 & 0.801 \\
\hline July & 9.41 & 1.68 & 7.73 & 0.21 & 7.52 & 0.179 & 0.023 & 0.798 \\
\hline Aug & 9.59 & 1.76 & 7.83 & 0.21 & 7.62 & 0.183 & 0.022 & 0.795 \\
\hline Sep & 9.16 & 1.62 & 7.54 & 0.21 & 7.33 & 0.177 & 0.023 & 0.800 \\
\hline$O c t$ & 8.14 & 1.27 & 6.87 & 0.18 & 6.69 & 0.156 & 0.023 & 0.822 \\
\hline Nov & 6.75 & 0.89 & 5.86 & 0.16 & 5.70 & 0.132 & 0.024 & 0.844 \\
\hline$D e c$ & 6.18 & 0.66 & 5.52 & 0.15 & 5.37 & 0.107 & 0.025 & 0.868 \\
\hline Year & 8.38 & 1.283 & 7.10 & 0.1933 & 6.90 & 0.153 & 0.023 & 0.824 \\
\hline
\end{tabular}

TABLE 11

COST OF ELEMENTS USED IN SOLAR TRACKING SYSTEM

\begin{tabular}{|c|c|c|c|c|}
\hline No & $\begin{array}{c}\text { COST OF ELEMENTS L } \\
\text { Components }\end{array}$ & $\begin{array}{l}\text { IN SOL } \\
\text { price ( } \\
\text { EGP) }\end{array}$ & $\begin{array}{l}\text { IRACKING } \\
\text { Quantity }\end{array}$ & total \\
\hline 1 & PV modules $(1 \mathrm{~kW})$ & 6000 & 10 & 60000 \\
\hline 2 & mounting structure & 2000 & 10 & 20000 \\
\hline 3 & Inverter & 30000 & 1 & 30000 \\
\hline 4 & Cables & 60 & 15 & 900 \\
\hline 5 & cable trays & 20 & 20 & 400 \\
\hline 6 & protection box & 1000 & 1 & 1000 \\
\hline 7 & servo motor & 2000 & 1 & 2000 \\
\hline 8 & PCB+ control box & 2500 & 1 & 2500 \\
\hline 9 & Batteries & 1750 & 2 & 3500 \\
\hline 10 & Charger & 750 & 1 & 750 \\
\hline 11 & limit switches & 70 & 2 & 140 \\
\hline 12 & $\begin{array}{l}\text { solar panel(for } \\
\text { tracking system) }\end{array}$ & 2300 & 1 & 2300 \\
\hline 13 & installation cost & 10000 & 1 & 10000 \\
\hline 14 & transportation cost & 3000 & 1 & 3000 \\
\hline \multicolumn{4}{|c|}{ Total } & 136490 \\
\hline
\end{tabular}

TABLE 12

\begin{tabular}{|c|c|c|c|c|}
\hline No & $\begin{array}{l}\text { COST OF ELEMENT } \\
\text { Components }\end{array}$ & $\begin{array}{c}\text { SED IN SC } \\
\text { price ( } \\
\text { EGP) }\end{array}$ & $\begin{array}{l}\text { R FIXED SY } \\
\text { Quantity }\end{array}$ & total \\
\hline 1 & $P V$ modules $(1 \mathrm{~kW})$ & 6000 & 10 & 60000 \\
\hline 2 & mounting structure & 1300 & 10 & 13000 \\
\hline 3 & Inverter & 30000 & 1 & 30000 \\
\hline 4 & Cables & 60 & 15 & 900 \\
\hline 5 & cable trays & 20 & 20 & 400 \\
\hline 6 & protection box & 1000 & 1 & 1000 \\
\hline 7 & installation cost & 5000 & 1 & 5000 \\
\hline 8 & transportation cost & 3000 & 1 & 3000 \\
\hline \multicolumn{4}{|c|}{ Total } & 113300 \\
\hline
\end{tabular}

From the results in section 5; the annual plant production for the solar fixed system is $19456 \mathrm{kWh}$. The annual plant production for the solar tracking system is $25380 \mathrm{kWh}$. The price of the slide $10 \mathrm{~kW}$ in Egypt country is calculated with 1.10 EGP for each one kWh. From the results in table 11 and 12 , the price of each one $\mathrm{kWh}$ is calculated for the solar fixed 
and tracking system; the price of each one $\mathrm{kWh}$ is $0.233 \mathrm{EGP}$ for the solar fixed system. The price of each one $\mathrm{kWh}$ is 0.215 EGP for the solar tracking system. The percentage of increasing annual energy production for the solar tracking system is $30.488 \%$ more than the solar fixed system. Percentage of decreasing the price of each one $\mathrm{kWh}$ for the solar tracking system is $7.725 \%$ less than the solar fixed system.

\section{CONCLUSION}

This study worked on the sun-single axis tracking system in a large system size unlike other systems makes single axis tracking on small system size. The Energy production comparison between fixed and tracking solar system show that the total annual Production energy for fixed system is equal to 19.450 MWH while The total annual Production energy for tracking system is equal to $25.378 \mathrm{MWH}$, so the percentage of increasing annual energy production for the solar tracking system is $30.488 \%$ more than the solar fixed system. Economic comparison between fixed and tracking solar system show that the price of the slide $10 \mathrm{~kW}$ in Egypt country is calculated with 1.10 EGP for each one $\mathrm{kWh}$, the price of each one $\mathrm{kWh}$ is $0.233 \mathrm{EGP}$ for the solar fixed system while the price of each one $\mathrm{kWh}$ is 0.215 EGP for the solar tracking system, so the Percentage of decreasing the price of each one $\mathrm{kWh}$ for the solar tracking system is $7.725 \%$ less than the solar fixed system. The mechanical design is simple and uncomplicated as it did not contain Chains or hydraulic presses containing only Servo motor with gearbox. The electrical design is very good as the control circuit is small multiple tasks, it can control six motors from one place where the circuit is designed on the PCB (printed circuit board) and put with them the protectors, capacitors and fans needed for long periods in industrial environments or high temperatures conditions. The cost of this system is low because it does not require any photoelectric sensor and it does not contain any hydraulic presses.

\section{REFERENCES}

[1] Nadia AL-Rousan, Nor Ashidi Mat Isa, Mohd Khairunaz Mat D. Advances in solar photovoltaic tracking systems. Renewable and Sustainable Energy 2018; 82: 2548-2569.

[2] Borhanazad $\mathrm{H}$, et al. Potential application of renewable energy for rural electrification in Malaysia. Renew Energy 2013; 59:210-219.

[3] Arian Bahramia, Chiemeka Onyeka Okoye, The performance and ranking pattern of $\mathrm{PV}$ systems incorporated with solar trackers in the northern hemisphere. . Renewable and Sustainable Energy 2018; 97: 138-151.

[4] Mousazadeh H, Keyhani A, Javadi A, Mobli H, Abrinia K, Sharifi A. A review of principle and sun-tracking methods for maximizing solar systems output. Renew Sustain Energy Rev 2009; 13:1800-1818.

[5] Lave M, Kleissl J. Optimum fixed orientations and benefits of tracking for capturing solar radiation in the continental United States. Renew Energy $2011 ; 36: 1145-1152$.
[6] Kacira M, Simsek M, Babur Y, Demirkol S. Determining optimum tilt angles and orientations of photovoltaic panels in Sanliurfa, Turkey. Renew Energy 2004; 29:1265-75.

[7] A.Z. Hafez, A.M. Yousef, N.M. Harag. Solar tracking systems: Technologies and trackers drive types. Renewable and Sustainable Energy Reviews, 2018; 91:754-782.

[8] Zhao D, Xu E, Wang Z, Yu Q, Xu L, Zhu L. Influences of installation and tracking errors on the optical performance of a solar parabolic trough collector. Renew Energy 2016; 94:197-212.

[9] Roong ASC, Chong S-H. Laboratory-scale single axis solar tracking system: Design and implementation. Int J Power Electron Drive System 2016; 7:254-264.

[10] Basnayake BADJCK, Jayathilaka WADM, Amarasinghe YWR, Attalage RA, Jayasekara AGBP. Smart solar tracking and on-site photovoltic efficiency measurement system. 2016 Moratuwa Engineering Research Conference (MERCon) 2016; 54 - 59.

[11] Sallaberry F, Pujol-Nadal R, Larcher M, Rittmann-Frank MH. Direct tracking error characterization on a single-axis solar tracker. Energy Conversion and Management 2015; 105:1281-1290.

[12] Sallaberry F, De Jalón AG, Torres J-L, Pujol-Nadal R. Optical losses due to tracking error estimation for a low concentrating solar collector. Energy Conversion and Management 2015; 92:194-206.

[13] Li L, Li H, Xu Q, Huang W. Performance analysis of Azimuth Tracking Fixed Mirror Solar Concentrator. Renewable Energy 2015; 75:722-732.

[14] Xing Zhikun. Research and Design of Control System of the Solar Panel Tracking 2016 IEEE Advanced Information Management, Communicates, Electronic and Automation Control Conference (IMCEC) 2016; $1384-1388$

[15] Mr. Sourabh Whavale, Mr. Mangesh Dhavalikar. A review of Adaptive solar tracking for performance Enhancement of solar power plant. 2018 International Conference on Smart City and Emerging Technology (ICSCET).

[16] Yiwang Wang, Jia Song. Design of a Digital Solar Panel Automatic Tracking Controller for Photovoltaic Generation System. 2012 AsiaPacific Power and Energy Engineering Conference.

[17] Saad Motahhir, Aboubakr EL Hammoumi, Abdelaziz EL Ghzizal, Aziz Derouich. Open hardware/software test bench for solar tracker with virtual Instrumentation. Sustainable Energy Technologies and Assessments 2019; 31:9-16.

[18] Mousazadeh H, Keyhani A, Javadi A, Mobli H, Abrinia K, Sharifi A. A review of principle and sun-tracking methods for maximizing solar systems output. Renew Sustain Energy Rev 2009; 13 (8):1800-1818.

[19] Wu J, Chen X, Wang L. Design and dynamics of a novel solar tracker with parallel mechanism. IEEE/ASME Trans Mechatronic 2016; 21(1):88-97.

[20] Benghanem M. Optimization of tilt angle for solar panel: case study for Madinah, Saudi Arabia. Appl. Energy 2011; 88(4):1427-33.

[21] Poulek V, Khudysh A, Libra M. Self-powered solar tracker for low concentration PV (LCPV) systems. Solar Energy 2016; 127:109-112.

[22] Visconti P, Costantini P, Orlando C, Lay-Ekuakille A, Cavalera G. Software solution implemented on hardware system to manage and drive multiple bi-axial solar trackers by PC in photovoltaic solar plants. Measurement 2015; 76:80-92.

[23] Amogha Lokesh, Anup Surahonne, Adithya N Simha, Arjuna C Reddy. Solar Tracking System Using Microcontroller. 2014 1st International Conference on Non-Conventional Energy (ICONCE 2014) 2014; 77 79.

[24] Duy C. Huynh, Tuong M.Nguyen, Duy C. Huynh, Tuong M.Nguyen, Markus A. Mueller. Comparison between Open- and Closed-Loop Trackers of a Solar Photovoltaic System. 2013 IEEE Conference on Clean Energy and Technology (CEAT) 2013; 128 - 133.

[25] Mostefa Ghassoul. Single axis automatic tracking system based on PILOT scheme to control the solar panel to optimize solar energy extraction. Energy Reports 2018; 4:520-527.

[26] Jerin Kuriakose, Andrew Keong. Design and Development of an Automatic Solar Tracker. Energy Procedia 2017; 143: 629 - 634. 
TABLE 9

THE MONTHLY HOURLY SUMS PRODUCTION ENERGY FOR FIXED SOLAR SYSTEM

\begin{tabular}{c||c||c||c||c||c||c||c||c||c||c||c||c||c||c||}
\multicolumn{1}{l|}{} & $5 H$ & $6 H$ & $7 H$ & $8 H$ & $9 H$ & $10 H$ & $11 H$ & $12 H$ & $13 H$ & $14 H$ & $15 H$ & $16 H$ & $17 H$ & $18 H$ \\
\hline January & 0 & 0 & 59 & 124 & 172 & 205 & 217 & 216 & 201 & 166 & 115 & 52 & 0 & 0 \\
\hline February & 0 & 0 & 55 & 121 & 169 & 202 & 213 & 214 & 197 & 170 & 124 & 61 & 1 & 0 \\
\hline March & 0 & 10 & 78 & 148 & 200 & 231 & 244 & 243 & 227 & 195 & 144 & 75 & 6 & 0 \\
\hline April & 0 & 25 & 88 & 149 & 193 & 218 & 229 & 227 & 208 & 175 & 125 & 64 & 10 & 0 \\
\hline May & 1 & 31 & 90 & 147 & 187 & 211 & 219 & 215 & 197 & 165 & 118 & 58 & 11 & 0 \\
\hline June & 4 & 31 & 88 & 144 & 185 & 208 & 218 & 215 & 199 & 169 & 122 & 64 & 17 & 0 \\
\hline July & 1 & 27 & 83 & 142 & 185 & 211 & 222 & 220 & 205 & 176 & 130 & 70 & 19 & 0 \\
\hline August & 0 & 26 & 87 & 149 & 193 & 219 & 230 & 228 & 211 & 181 & 132 & 70 & 14 & 0 \\
\hline September & 0 & 28 & 92 & 152 & 193 & 216 & 226 & 220 & 204 & 169 & 120 & 56 & 3 & 0 \\
\hline October & 0 & 30 & 95 & 158 & 198 & 223 & 225 & 219 & 193 & 155 & 101 & 38 & 0 & 0 \\
\hline November & 0 & 5 & 77 & 142 & 169 & 194 & 208 & 202 & 185 & 143 & 85 & 14 & 0 & 0 \\
\hline December & 0 & 1 & 68 & 135 & 174 & 200 & 211 & 198 & 176 & 139 & 84 & 13 & 0 & 0 \\
\hline Year & 6 & 214 & 962 & 1711 & 2220 & 2538 & 2662 & 2616 & 2404 & 2003 & 1400 & 635 & 80 & 0
\end{tabular}

TABLE 10

THE MONTHLY HOURLY SUMS PRODUCTION ENERGY FOR TRACKING SOLAR SYSTEM

\begin{tabular}{c||c||c||c||c||c||c||c||c||c||c||c||c||c||c}
\multicolumn{1}{c||}{} & $5 H$ & $6 H$ & $7 H$ & $8 H$ & $9 H$ & $10 H$ & $11 H$ & $12 H$ & $13 H$ & $14 H$ & $15 H$ & $16 H$ & $17 H$ & $18 H$ \\
\hline January & 0 & 0 & 130 & 182 & 204 & 217 & 218 & 217 & 214 & 200 & 172 & 117 & 1 & 0 \\
\hline February & 0 & 5 & 121 & 183 & 204 & 215 & 215 & 215 & 208 & 201 & 183 & 125 & 9 & 0 \\
\hline March & 0 & 56 & 165 & 220 & 240 & 245 & 245 & 244 & 242 & 236 & 218 & 163 & 38 & 0 \\
\hline April & 3 & 108 & 179 & 215 & 227 & 229 & 230 & 230 & 226 & 218 & 199 & 160 & 93 & 0 \\
\hline May & 15 & 123 & 181 & 211 & 220 & 221 & 220 & 219 & 216 & 209 & 193 & 154 & 89 & 1 \\
\hline June & 11 & 124 & 186 & 212 & 219 & 220 & 219 & 218 & 216 & 213 & 199 & 164 & 93 & 1 \\
\hline July & 10 & 119 & 185 & 214 & 222 & 224 & 223 & 222 & 221 & 218 & 206 & 175 & 104 & 4 \\
\hline August & 4 & 112 & 187 & 219 & 229 & 232 & 231 & 230 & 228 & 223 & 209 & 172 & 100 & 1 \\
\hline September & 1 & 115 & 181 & 213 & 223 & 225 & 226 & 224 & 222 & 213 & 195 & 143 & 32 & 0 \\
\hline October & 0 & 107 & 172 & 212 & 224 & 230 & 225 & 224 & 213 & 199 & 170 & 111 & 1 & 0 \\
\hline November & 0 & 19 & 136 & 189 & 190 & 200 & 208 & 206 & 204 & 185 & 142 & 44 & 0 & 0 \\
\hline December & 0 & 6 & 131 & 189 & 201 & 209 & 211 & 200 & 191 & 172 & 132 & 34 & 0 & 0 \\
\hline Year & 44 & 893 & 1954 & 2459 & 2604 & 2666 & 2671 & 2650 & 2602 & 2489 & 2219 & 1561 & 559 & 7
\end{tabular}

